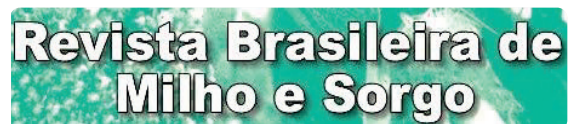

Brazilian Journal of Maize and Sorghum

ISSN 1980 - 6477

Journal homepage: www.abms.org.br/site/paginas

Thays Gabriella Lima Silva ${ }^{(1)}$, Romano Roberto Valicheski $^{(1)}(\bowtie)$, Flávio Lopes Cláudio ${ }^{(1)}$, Estênio Moreira Alves ${ }^{(1)}$, Mateus de Sousa Peres ${ }^{(1)}$ and Paulo Alexandre Perdomo Salviano ${ }^{(1)}$

(1) Instituto Federal Goiano - Campus Iporá,

E-mail: thayslima.agro@gmail.com

romano.roberto@ifgoiano.edu.br

flavio.claudio@ifgoiano.edu.br

estenio.moreira@ifgoiano.edu.br

mateusperes20@gmail.com

paulo.salviano@ifgoiano.edu.br

Corresponding author

How to cite

SILVA, T. G. L.; VALICHESKI, R. R.; CLÁUDIO, F

L.; ALVES, E. M.; PERES, M. S.; SALVIANO, P. A

P. Silage production, bromatological composition

and economic viability of inoculation of varietal maizes with Azospirillum brasilense. Revista

Brasileira de Milho e Sorgo, v. 20, e1174, 2021.

\section{SILAGE PRODUCTION, BROMATOLOGICAL COMPOSITION AND ECONOMIC VIABILITY OF INOCULATION OF VARIETAL MAIZES WITH} Azospirillum brasilense

\begin{abstract}
In the western region of the State of Goias family farmers that depend on the raising of livestock as one of their main sources of income are predominant. These farmers periodically grow maize for the production of silage in order to compensate their incomes. Considering the high cost of hybrid seeds and nitrogen fertilization, technologies that contribute to the reduction of silage production costs are required. In this sense, the objective of this study was to evaluate the response of maize genetic materials (Feroz Hybrid VIP3 and varieties SCS 156 and SCS 154), regarding silage production, bromatological composition and economic viability when inoculated with Azospirillum brasilense. The experiment was carried out on strips using a completely randomized design with four replications. Each cultivar responded differently to inoculation. For the Feroz hybrid and SCS 156 variety, the use of Azospirillum provided increases of $13.1 \%$ and $42.1 \%$ in green stem mass and 11.2 and $30.3 \%$ in silage nitrogen content, influencing the nutritional composition of the bulky food produced. For the SCS 154 variety, there was no response to inoculation. As for the economic viability, the use of inoculated SCS 156 variety presents a better rate of rentability, proving to be more economically attractive and viable to farmers.
\end{abstract}

Keyword: family farming, silage production, inoculation, economic viability

\section{PRODUÇÃO DE SILAGEM, COMPOSIÇÃO BROMATOLÓGICA E VIABILIDADE ECONÔMICA DE MILHOS VARIEDADE INOCULADOS COM Azospirillum brasilense}

\begin{abstract}
Resumo - Na região do Oeste Goiano há um predomínio de agricultores familiares. Estes têm a pecuária como uma das principais atividades geradora de renda, cultivando periodicamente milho para produção de silagem. Considerando o elevado custo das sementes híbridas e da adubação nitrogenada, necessita-se de tecnologias que contribuam na redução dos custos de produção. Neste sentido, objetivou-se avaliar a resposta de materiais genéticos de milho (Híbrido Feroz VIP3 e variedades SCS 156 e SCS 154), quanto a produção de silagem, composição bromatológica e viabilidade econômica, quando inoculados com Azospirillum brasilense. O experimento foi implantado em faixas utilizando-se delineamento inteiramente casualizado, com quatro repetições. Os materiais genéticos responderam de forma diferenciada à inoculação. Para o híbrido Feroz VIP3 e variedade SCS 156, o uso de Azospirillum proporcionou incrementos de $13,1 \%$ e $42,1 \%$ na produção de massa fresca pela parte aérea e de 11,2 e $30,3 \%$ no teor de nitrogênio da silagem, influenciando na composição nutricional do alimento volumoso produzido. Já para a variedade SCS 154, não houve resposta a inoculação. Quanto a viabilidade econômica, o uso da variedade SCS 156 inoculada apresentou melhor taxa de rentabilidade, demonstrando ser economicamente mais atrativa e viável para os produtores rurais.
\end{abstract}

Palavras-chave: agricultura familiar, produção de silagem, inoculação, viabilidade econômica. 
In the municipality of Iporá, state of Goias, Brazil, as well as the surrounding areas, the predominant agricultural activity is the production of cattle for meat and milk. These activities function as the main source of income for these rural establishments (Dias et al., 2015). Along with these activities, the cultivation of cereals is of significant importance especially that of maize for silage, ears and stalks, utilized as feed for the herds, especially during the dry season.

The region is mostly comprised of small rural properties, with sizes no greater than 100 hectares whom are predominantly run as family farms (Dias et al., 2015).

Despite the use of hybrid seeds that have elevated silage yields, it has been observed with some frequency that the local growers are usually dissatisfied with the total produced biomass and the quality of the grain. This fact is due to the elevated demand of agricultural inputs required by these hybrid maizes in order to reach their full productive potential; inputs that are many times either nonexistent or supplied in inferior quantity by these rural properties.

Due to these conditions, one of the ways to diminish the costs of production and increase the economic feasibility of maize production is to utilize more cost effective cultivars that present a decreased input demand. For this, heirloom and open pollination variety seeds stand out whenever they have an adequate yield, good climate and soil adaptability, low input costs and also allow for the farmer to produce his own seeds for subsequent harvests (Cruz et al., 2011).

In the production of maize, one of the most demanded nutrients is nitrogen $(\mathrm{N})$. Because of the low purchasing power of these family farms, there exists an insufficient supply of nitrogenized fertilizers. This fact, associated to an also diminished intake rate, usually no greater than $50 \%$ of the applied total (Hungria, 2011), contributes to the area's low crop output.

Confronted by this situation, biological alternatives that assist in the supply of $\mathrm{N}$ to the plants must be established. For example, the use of bacterium belonging to the genus Azospirillum, which possess the capacity of enhancing biological nitrogen fixation (Dobbelaere et al., 2001) and contribute to the production of plants growth stimulating hormones, (Szilagyi-Zecchin et al., 2015), are interesting due to the possibility of their contributions to the plant development and greater crop yield.

According to Hungria et al. (2010), the harvesting of maize utilizing these bacteria, associated with the supplementation of $30 \mathrm{~kg} \mathrm{ha}^{-1}$ of $\mathrm{N}$, can produce a grain yield of 7,000 kg per hectare or more. These bacteria can stimulate the plants growth by the combination of diverse mechanisms. Their capacity of biological fixation of nitrogen (Mumbach et al., 2017, Shaeffer et al., 2019), the solubilizing of phosphates (Rodriguez et al., 2004), and the production of phytohormones that stimulate root growth are some of these mechanisms (Szilagyi-Zecchin et al., 2015).

The stimulus in radicular development provided to plants inoculated with Azospirillum, can bring forth other beneficial effects like an increase in water and nutrient uptake, a greater tolerance to saline and hydric stresses, resulting in many cases with vigorous plant development (Skonieski et al., 2017, Morais et al., 2017, Souza, et al., 2019).

Inoculation can also induce diverse physiological responses, such as an improvement of photosynthetic parameters (chlorophyll content and stomatal conductance), greater hydric potential, 
greater cellular wall elasticity, and an increase in biomass, plant height and productivity (Cunha et al. 2014, Skonieski et al. 2017, Szilagyi-Zecchin et al. 2017, Thomazini et al. 2019).

Considering the overall level of lack of financial capital by the region's growers and the benefits that the use of variety maize and of these bacterial inoculants can bring forth, the aiming of this work was to evaluate the responses of different maize varieties in silage yield, bromatological composition and economic feasibility, when inoculated with Azospirillum brasilense.

\section{Material and Methods}

In order to tend to the proposed objectives, an experiment was conducted during the 2018/19 harvest, at the Estancia Santa Ines farm, located in the municipality of Diorama, state of Goias, Brazil. With specific coordinates at $16^{\circ} 17^{\prime} 03^{\prime}$ 'S and $51^{\circ} 30^{\prime} 04^{\prime \prime} \mathrm{W}$ and an altitude of $354 \mathrm{~m}$ above sea-level, the region's climate is Aw, according to the Köppen scale. As a tropical savannah, the location has an average annual temperature of $24.4{ }^{\circ} \mathrm{C}$, well defined rainy and dry seasons and an average annual precipitation of 1613 mm (Alves \& Biudes, 2008).

The studies area (of approximately 2.0 hectares) silage maize was cultivated conventionally for two consecutive years. So, previously to the experiment's implementation, a digital compaction rod (Model PenetroLOG - PGL 1020) was used to determine the soil's mechanical resistance to penetrations of up to $0.4 \mathrm{~m}$. Deformed samples of soil of depths ranging from ground level to $0.2 \mathrm{~m}$ were collected in order to perform a chemical and granulometric analysis.
It was verified through the soil penetration analysis that there was a soil compaction issue between 0.1 and $0.25 \mathrm{~m}$ in depth. In order to improve the physical condition of the soil before planting, the area was plowed to a depth of $0.3 \mathrm{~m}$ and lightly harrowed twice.

In relation to the soil's chemical composition, the analysis performed following Embrapa (2017) revealed a $\mathrm{pH}(\mathrm{CaCl})$ of 5.9 and Calcium $(\mathrm{Ca})$, Magnesium ( $\mathrm{Mg}$ ) and Aluminum (Al) levels of 6.3, 1.7 and $0.0 \mathrm{cmol}_{\mathrm{c}} / \mathrm{dm}^{3}$ respectively. Available phosphorous $(\mathrm{P})$ and interchangeable potassium $(\mathrm{K})$ were measured at 80 and $170 \mathrm{mg} \cdot \mathrm{dm}^{3}$, while sulphur $(\mathrm{S})$, boron $(\mathrm{B})$, copper $(\mathrm{Cu})$, iron $(\mathrm{Fe})$, manganese $(\mathrm{Mn})$ and zinc $(\mathrm{Zn})$ recorded at $0.4,0.2,0.3,43,85$ and $3.5 \mathrm{mg} / \mathrm{dm}^{3}$ respectively. Also, the soil presented an organic matter content of $23 \mathrm{~g} \cdot \mathrm{kg}^{-1}$ and a base saturation of $81 \%$. In regards to the granulometric composition, the soil contained 230 g. $\mathrm{kg}^{-1}$ of clay, 190 g. $\mathrm{kg}^{-1}$ of silt and 580 g. $\mathrm{kg}^{-1}$ of sand and was classified with a sandy clay loam texture.

The experiment had a completely randomized factorial design of $3 \times 2$, in which three different genetic maize materials where utilized (Feroz VIP3 hybrid and the varieties SCS 156 - Colorado and SCS-154 Fortuna), with and without inoculation of Azospirillum and were repeated 4 times.

Strips were formed in the experiments area and during planting time (25/10/2018), $0.8 \mathrm{~m}$ spacing between rows were sown with 63 thousand seeds per hectare. Fertilization protocols followed those of Embrapa (2004), applying $180 \mathrm{~kg} \cdot \mathrm{ha}^{-1}$ of monoammonium phosphate (MAP) in the furrow.

The inoculation of a commercial product AzzoFix ${ }^{\circledR}$ (Azospirillum brasilense, Strands AbV5 and AbV6, and concentration of $2 \times 10^{8} \mathrm{UFC} \mathrm{mL}^{-1}$ ), was done through spraying the seeds before planting 
at dosages of $200 \mathrm{~mL} \cdot \mathrm{ha}^{-1}$ and then letting them dry in a shaded area until completely dry.

With regards to the applied phytosanitary treatments, due to an intense infestation of stink bugs (Dichelops melacanthus and Dichelops furcatus), two applications of a cyhalotrin based insecticide were applied at days 18 and 27 after planting at dosages of $0.25 \mathrm{~L} \mathrm{ha}^{-1}$, which also assisted in the control of the fall armyworm (Spodoptera frugiperda).

In order to combat, weeds, primarily crabgrasses (Digitaria sp.), a mesotrione based herbicide was introduced at day 40 in dosage of 280 g. a.i. ha ${ }^{-1}$. Also, a topdressing was applied twice, the first at day 15 , with a dosage of $100 \mathrm{~kg} \cdot \mathrm{ha}^{-1}$ of 20-0020 compound and then at day $25,100 \mathrm{~kg} \cdot \mathrm{ha}^{-1}$ of urea.

Due to a small change in weather patterns that occurred during the first fortnight of January 2018, a reduction of all of the test subjects cycles was necessary, forcing silage cut only 82 days after planting. At this time, each experimental parcel had plants gathered randomly from 2 linear meters of the crop area, and the plant stand variables were collected: height of first ear, plant height, number of maize ears per plant and green aerial mass. Following the sample collection, the plants were shredded using a foliage shredder (model EN-12B), in order to oven dry at $65^{\circ} \mathrm{C}$ until constant mass, for the measuring of dry mass content.

In order to determine the silage characteristics, a small bin made out of PVC pipes (100 $\mathrm{mm}$ in diameter by $300 \mathrm{~mm}$ in length) were constructed for each sample. Sealed at both ends by PVC stoppers, a standard compaction was achieved by adding a total mass of $2.7 \mathrm{~kg}$ of silage to each silo. The material was acclimatized during a 60 day period, followed by an analysis of $0.5 \mathrm{~kg}$ of each of the stored materials. These samples were then dried in a forced circulation oven at $65^{\circ} \mathrm{C}$, ground using a Willye type mill and stored in sealed plastic bags until they were analyzed.

Following the methodology described by Tedesco (1995), the sulfuric digestion of the plant tissue and the determination of the total nitrogen content were carried out by the micro Kjeldahl method. In order to obtain the gross protein value, the nitrogen content was multiplied by a factor of 6.25 (Rodrigues, 2010).

The determination of fiber in acid detergent (FAD) was performed in borosilicate glass filter crucibles with porous plate of medium to coarse porosity, 100 to $160 \mathrm{~mm}$ (Rodrigues, 2010). In respect to the FAD data, and following the recommendations of the author, total digestible nutrients (TDN), dry mass digestibility (DMD), digestible energy (DE), metabolic energy (ME), raw fiber (RF) and the net energy gain (NEG) were also obtained.

After tabulating the data, they were submitted to a variance analysis. When a significant effect of the inoculation was detected, the means were compared to each other using a Tukey test, considering a 5\% probability of error, utilizing the SASM-Agri program (Canteri et al., 2001).

For the construction of the necessary cash flows in order to establish the experiments economic indicators, the total expenses for three consecutive years were considered. The agricultural inputs, mechanized activities and labor requirements of the first harvest were repeated for years two and three. An exception was made, as liming was required at the beginning of the second harvest, after a soil analysis collected at depths of up to $0.2 \mathrm{~m}$, presented some soil depletions right after the initial harvest. For net income, the market value of the first harvest's yield for each sample was also used for years two and three. 
As land costs, the average lease price for the region was utilized, considering a 4-month cultivation period for each of the three years destined exclusively of the production of silage.

To verify the economic and financial feasibility of the proposed study, the production cost vs return of investment was analyzed for each stage of the activity. Since this is a comparative evaluation of varieties from the perspective of different answers for each period analyzed, we sought to consider the relational rate of rentability and profitability under investment as ideal in the economic-financial analysis, as it is an easy-to-use methodology measurement and understanding of the growers. In this sense, the rentability was calculated by evaluating the net profit divided by the total cost of investment and the profitability by dividing the net profitably the total revenue, which was obtained multiplying the market value of silage times the yield of each treatment.

This financial evaluation, in a way, presents itself as simplistic, but for this type of short-term conditions evaluation it is significant and meets the central question of this paper. It enables the local producers to analyze the opportunity costs of purchasing or producing their own silage, as well as allowing them to evaluate which inoculated varieties presents the greatest return rates for their investments.

\section{Results and discussion}

Both the maize varieties and the use of Azospirillum brasilense influenced the variables evaluated (Table 1). For the number of plants.ha-1 (Pl/ha), plant height (HGT), green mass yield per plant (GMP) and aerial dry mass yield (ADM) and total accumulated protein in dry mass (PDM), there were isolated effects caused by the different variety lines. As for the variables GMP, green aerial mass yield (GAM), and PDM, there were isolated effects caused by inoculation. As for the interaction of factors (prioritized in the interpretation of the results), there was a significant effect at the first ear's insertion height (FEIH); GMP, GAM, ADM, $\mathrm{N}$ content in silage (NCS), total protein in silage (TPS) and highly significant effect for PDM.

Regarding the isolated effect of the genetic materials of maize, despite using the same amount of seeds, the Feroz hybrid presented a greater plant

Table 1. Significance and $\mathrm{F}$ values of variances and variation coefficient (CV) for plants per hectare (Pl/ha); plant height (HGT); first ear insertion height (FEIH), number of ears per plant (NCP); green mass yield per plant (GMP); green aerial mass yield (GAM); aerial dry mass yield (ADM); nitrogen content in silage (NCS); total protein in silage (TPS); accumulated total protein in dry mass (PDM). Diorama-GO, 2018.

\begin{tabular}{lcccccccccc}
\hline V.S. & PI./ha & HGT & CIH & NCP & GMP & AGM & ADM & NCS & TPS & PDM \\
\hline V. & $8.1^{* *}$ & $4.23^{*}$ & $1.58^{\text {ns }}$ & $0.11^{\text {ns }}$ & $6.15^{*}$ & $1.50^{\text {ns }}$ & $4.59^{*}$ & $3.19^{\text {ns }}$ & $3.19^{\text {ns }}$ & $11.9^{* *}$ \\
I. & $1.12^{\text {ns }}$ & $0.94^{\text {ns }}$ & $0.07^{\text {ns }}$ & $0.14^{\text {ns }}$ & $9.38^{*}$ & $4.91^{*}$ & $1.34^{\text {ns }}$ & $4.14^{\text {ns }}$ & $4.13^{\text {ns }}$ & $8.32^{*}$ \\
V. x I. & $1.21^{\text {ns }}$ & $1.69^{\text {ns }}$ & $3.8^{*}$ & $0.36^{\text {ns }}$ & $7.12^{*}$ & $4.33^{*}$ & $3.91^{*}$ & $4.61^{*}$ & $4.61^{*}$ & $11.5^{* *}$ \\
\hline V.C. $(\%)$ & 15.1 & 7.1 & 9.2 & 19.9 & 25.5 & 14.3 & 17.4 & 11.4 & 11.4 & 15.8 \\
\hline
\end{tabular}

V.S.- variation source; V.- maize variety; I.- inoculation; V.C.- variation coefficient; $*<0,05$; $* *<0,01$; ns - no significance. 
stand count per hectare when compared to the maize varieties (Figure 1A). Considering that all genetic materials had germination power greater than $90 \%$ at the time of planting, the smaller grain sizes of the hybrid maize seeds when compared to the varieties, may have contributed to a better seed germination. During the first eight days after sowing there was no precipitation, a factor which may have limited the rehydration of larger seeds thus resulting in a lower germination rate. As for the plant heights (Figure 1B), variety SCS-156 was taller when compared to SCS154 , however, it did not differ statistically from the hybrid maize.

In general, maize varieties or open pollination plants have greater height than hybrid materials, as they are in a permanent evolutionary process and adaptation to environmental conditions and cultivation systems (Cruz et al., 2011). For Ferreira et al. (2009), native varieties are generally taller, with greater ear insertion heights yet have a higher frequency of bedridden or broken plants, when compared to more modern commercial cultivars. On the other hand, according to these authors, taller plants have advantages when used for animal feed, especially in the case of using whole plants silage. Furthermore, they contribute to greater production of straw on the ground.

As for the interaction effects, there was a different response of maize materials to inoculation with Azospirillum brasilense. Ear insertion heights (Figure 2A), presented no significant differences between the maize genotypes when inoculated. However, without inoculation, SCS-154 was statistically inferior to SCS-156, which did not differ statistically from Feroz VIP3. Considering the effect of inoculation within each genetic material of maize, for cultivar SCS-154, the use of Azospirilum provided an increase of $13.7 \%$ in the ear insertion height for the first ear. In contrast, for Feroz VIP3 and SCS-156, there was no significant effect on this variable caused by inoculation.

As for the production of green mass yield per plant (Figure 2B) and total green mass yield per hectare (Figure 2C), when inoculated with Azospirillum, SCS -156 was statistically superior to variety SCS 154 and similar to Hybrid Feroz VIP3. Without inoculation, there was no statistical difference between the genetic materials of the tested maize, a fact that demonstrates
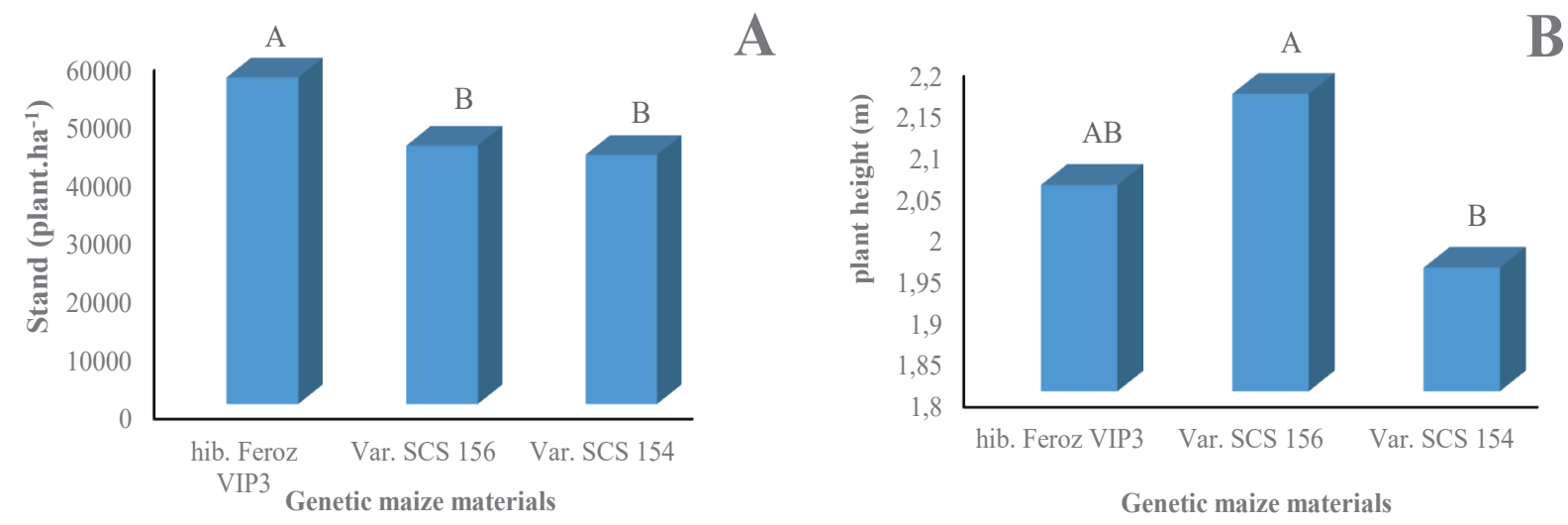

Figure 1. Isolated effects of maize variety for stand count (A) and plant height (B). Values followed by the same letter do not differ between themselves by Tukey at the 5\% probability. Diorama-GO, 2018. 


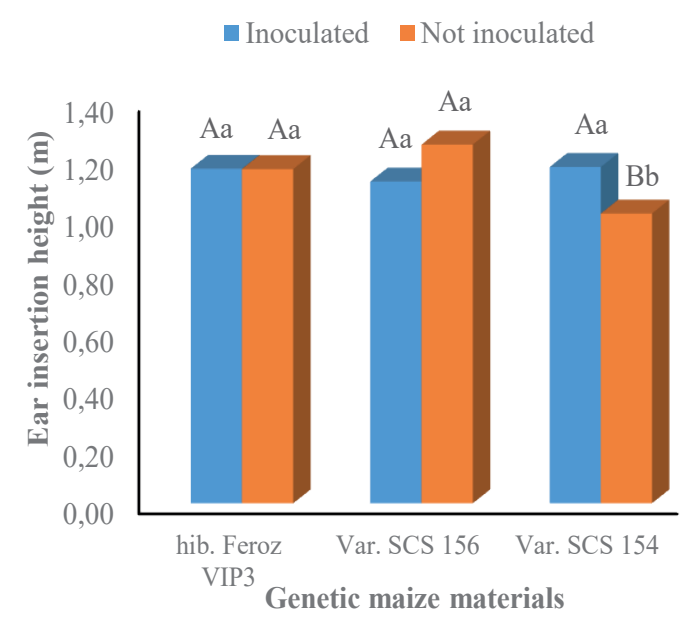

A
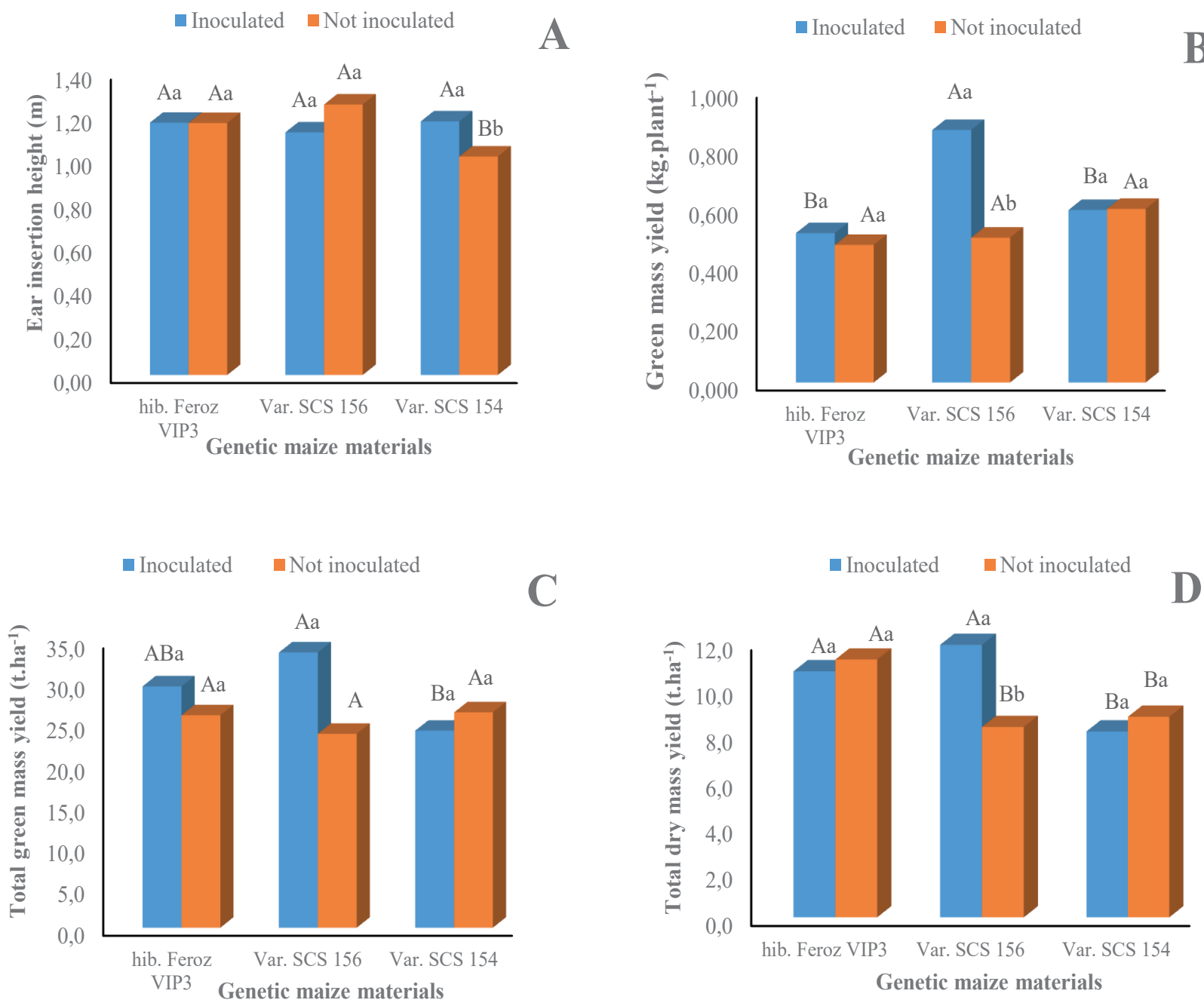

Figure 2. Effect of maize variety factor $x$ inoculation interaction for ear insertion heights (A), green mass yield per plant (B), total green mass yield (C) and total dry mass yield per hectare (D). Uppercase letters compare the effect of maize genetic materials in the presence and absence of Azospirillum brasilense and lowercase letters compare the effect of inoculation within each maize genetic material. Values followed by the same letter do not differ from each other by Tukey test at 5\% probability. Diorama-GO, 2018.

the potential of the varieties in terms of their yield capacity for bulky silage feed, since they did not differ from the hybrid. Inoculated Feroz VIP3 and SCS-154 (Figure 2C), presented an increase of 14.1\% and $39.2 \%$ respectively for the green aerial mass yield, a fact that suggests a better interaction of this bacterium with maize varieties. This is supported by the fact that the response of SCS-156 to the presence of Azospirillum brasilense resulted in an increase of $42.0 \%$ the total green aerial mass yield.

Regarding the total production of dry matter per hectare (Figure 2D), when inoculated, the Feroz 
VIP3 Hybrid and SCS-156 Variety did not differ statistically from each other, but both were superior to SCS-154, producing respectively $32.3 \%$ and $46.5 \%$ more dry matter. When no inoculate is added, the Feroz VIP3 Hybrid was superior to the maize varieties, with a production $35.4 \%$ higher than that obtained for SCS-156 and 28.6\% higher than that of SCS-154. Inoculation did not, however, present a particular effect in the hybrid and SCS-154, when measuring the dry matter of the plants aerial section, while for SCS-156 variety, there was an increase of $43.1 \%$.

This differentiated responses of each maize genetic material to inoculation are quite complex and depend on a series of environmental factors, from the plant and the bacteria itself. These complexities can cause a positive response to the inoculate in one season and not the next, as reported by Skonieski et al. (2017) for maize grown in the analyzed harvests from 2012 to 2014 .

In those treatments that were inoculated, the increase in the accumulation of dry mass in the aerial sections of the plant may be associated with several factors, including the ability of Azospirillum brasilense to fix atmospheric nitrogen (Shaeffer et al., 2019), to stimulate the production of phyto-hormones such as auxins, gibberellins and cytokines (SzilagyiZecchin et al., 2015), contributing to greater formation of root hairs and secondary roots, and consequently, in a greater root surface area for the absorption of water and nutrients. In addition, another factor that may have contributed is its ability to increase phosphorus availability (Rodriguez et al., 2004), resulting in greater plant development and yield (Thomazini et al., 2019). These factors, associated with a possible better interaction of the bacteria with the SCS-156 variety, may have contributed to the greater development of the plants when inoculated, thus resulting in a greater production of green and dry mass observed in the aerial sections.

Skonieski et al. (2017), evaluated the effect of Azosopirillum inoculation in different hybrid maize and observed that for the Defender hybrid, this practice resulted in an increase of $4.8 \%$ in dry mass yield, while for Hybrid AS-1572 there was a reduction of $3.4 \%$. Despite this variability in the response to inoculation, Diaz-Zorita (2012) reports that the biological treatment of seeds with diastrophic bacteria makes an important contribution to the vegetative growth of plants, and that inoculation associated with the supply of mineral nitrogen is efficient in most of cases in providing better development and productivity of plants, as observed by Morais et al. (2017); Skonieski et al. (2017); Szilagyi-Zecchin et al. (2017); Schaefer et al. (2019).

When non-inoculated and compared to hybrid maize, the SCS-156 and SCS-154 varieties, despite having a lower total dry mass yield (Figure 2D), were promising in the production of green mass for silage, not being differentiable in the parameter from the Feroz VIP3 hybrid (Figure 2C). This data reinforces the potential use of these variety seeds, primarily by those small rural growers that are predominant in the western regions of Goias, whom, due to the low/medium level of technology adopted in their properties, require seeds with lower acquisition costs.

Regarding the nutritional and chemical composition of the analyzed silage feed (Table 2), it is observed that for the $\mathrm{N}$ content, total protein and total protein accumulated in dry mass aerial, both the type of maize and the inoculation with Azospirillum significantly influenced these variables. As for the fiber in acid detergent (FAD), total digestible nutrients (TDN), dry mass digestibility (DMD), digestible 
energy (DE), metabolizable energy (ME); raw fiber (RF) and net energy gain (NEG), there was no effect of these factors.

When comparing the genetic materials of maize that were inoculated, Feroz and SCS-156 presented an increase in the nitrogen and total protein content of the feed, as well as in the total mass of accumulated protein in the silage $\left(\mathrm{kg} \cdot \mathrm{ha}^{-1}\right)$. These results showed to be statistically superior to SCS-154 (Table 2). When not inoculated, the hybrid was superior to both varieties in terms of nitrogen content and total protein accumulated per hectare. In this condition, the better performance of the hybrid is possibly related to the genetic improvements that it underwent, seeking to maximize grain production, which consequently results in more nutritious silage feed.
Considering the effects that inoculation had within each genetic material of maize, similarly to that observed for biometric variables (Figure 2 ), the plants responded differently to inoculation. This suggests that the cultivar or genetic material used is a factor that influences the efficiency of inoculation. This might possibly be caused due to the specificities of the bacterial flora and the host plant (Hungria, 2011). According to Marini et al. (2015), the effects of nitrogen fertilization and inoculation with Azospirillum brasilense on maize nutrition and productivity are also dependent on the genetic material used, however, according to Cunha et al. (2014), Moraes et al. (2017) and Scheafer et al. (2019), although this practice contributes to increasing leaf $\mathrm{N}$ concentration, it does not replace

Table 2. $\mathrm{N}$ content, total protein content (TPC), total accumulated protein in dry mass aerial (TAP), fiber in acid detergent (FAD), total digestible nutrients (TDN), dry mass digestibility (DMD), digestible energy (DE), metabolic energy (ME); raw fiber (RF) and net energy gain (NEG) of silage material of the maize cultivars, inoculated and not inoculated with Azospirillum brasilense. Diorama-GO, 2018.

\begin{tabular}{|c|c|c|c|c|c|c|}
\hline \multirow[b]{2}{*}{ Variável } & \multicolumn{2}{|c|}{ Hib. Feroz } & \multicolumn{2}{|c|}{ Var. SCS 156} & \multicolumn{2}{|c|}{ Var. SCS 154} \\
\hline & Inoculated & $\begin{array}{c}\text { Not } \\
\text { inoculated }\end{array}$ & Inoculated & $\begin{array}{c}\text { Not } \\
\text { inoculated }\end{array}$ & Inoculated & $\begin{array}{c}\text { Not } \\
\text { inoculated }\end{array}$ \\
\hline $\mathrm{N}$ content $\left(\mathrm{g} \cdot \mathrm{kg}^{-1}\right)$ & $16.63 \mathrm{Aa}$ & $14.88 \mathrm{Aa}$ & $15.97 \mathrm{Aa}$ & $12.25 \mathrm{Bb}$ & $13.13 \mathrm{Ba}$ & $14.44 \mathrm{Ba}$ \\
\hline ТРC (\%) & $10.4 \mathrm{Aa}$ & $9.3 \mathrm{Aa}$ & $9.98 \mathrm{Aa}$ & $7.66 \mathrm{Ab}$ & $8.2 \mathrm{Ba}$ & $9.02 \mathrm{Aa}$ \\
\hline TAP $\left(k g \cdot h^{-1}\right)$ & $1105.8 \mathrm{Aa}$ & $1030.7 \mathrm{Aa}$ & $1175.8 \mathrm{Aa}$ & $629.6 \mathrm{Bb}$ & $660.9 \mathrm{Ba}$ & $778.1 \mathrm{Ba}$ \\
\hline FAD $(\%)$ & $37.2 \mathrm{Aa}$ & $35.4 \mathrm{Aa}$ & $34.1 \mathrm{Aa}$ & $34.9 \mathrm{Aa}$ & $36.9 \mathrm{Aa}$ & $35.2 \mathrm{Aa}$ \\
\hline TDN (\%) & $61.8 \mathrm{Aa}$ & $63.0 \mathrm{Aa}$ & $64.0 \mathrm{Aa}$ & $63.4 \mathrm{Aa}$ & $62.0 \mathrm{Aa}$ & $63.1 \mathrm{Aa}$ \\
\hline DMD (\%) & $59.9 \mathrm{Aa}$ & $61.3 \mathrm{Aa}$ & $62.3 \mathrm{Aa}$ & $61.7 \mathrm{Aa}$ & $60.1 \mathrm{Aa}$ & $61.5 \mathrm{Aa}$ \\
\hline $\mathrm{DE}(\%)$ & $2.71 \mathrm{Aa}$ & $2.78 \mathrm{Aa}$ & $2.82 \mathrm{Aa}$ & $2.80 \mathrm{Aa}$ & $2.73 \mathrm{Aa}$ & $2.79 \mathrm{Aa}$ \\
\hline ME (\%) & $2.23 \mathrm{Aa}$ & $2.28 \mathrm{Aa}$ & $2.31 \mathrm{Aa}$ & $2.29 \mathrm{Aa}$ & $2.24 \mathrm{Aa}$ & $2.29 \mathrm{Aa}$ \\
\hline RF (\%) & $30.9 \mathrm{Aa}$ & $29.4 \mathrm{Aa}$ & $28.3 \mathrm{Aa}$ & $29.0 \mathrm{Aa}$ & $30.6 \mathrm{Aa}$ & $29.2 \mathrm{Aa}$ \\
\hline NEG (\%) & $0.36 \mathrm{Aa}$ & $0.38 \mathrm{Aa}$ & $0.39 \mathrm{Aa}$ & $0.38 \mathrm{Aa}$ & $0.36 \mathrm{Aa}$ & $0.38 \mathrm{Aa}$ \\
\hline
\end{tabular}

Uppercase letters compare the effect of maize genetic materials in the presence and absence of Azospirillum brasilense and lowercase letters compare the effect of inoculation within each maize genetic material. Values followed by the same letter do not differ from each other by Tukey test at $5 \%$ probability. 
nitrogen fertilization in its entirety.

There is a direct relationship between grain formation and metabolite translocation in the maize plant. Thus, according to the results obtained for hybrid Feroz VIP3 and SCS-156 variety, seed inoculation with Azospirillum brasilense contributed to a better nitrogen supply for the plants, resulting in greater shoot development (Figures 2C and 2D), as well as for an improved nutritional composition of the silage feed made from these samples.

Thus, considering that the same dose of nitrogen was applied to all treatments, only for Feroz and for SCS-156 did this practice seem to contribute to the increase in efficiency of the plant's nitrogen uptake. On the other hand, for variety SCS-154, the lack of response to inoculation regarding the chemical composition of the silage (Table 2), as well as regarding the biometric parameters evaluated in the aerial part (Figures 2B, 2C and 2D), suggest that the bacterial $\mathrm{v}$. host interaction was inefficient under the conditions in which this work was developed.

The factors that have the greatest effect in the crops responses to inoculation are still not fully understood. For Marini et al. (2015), the effects of nitrogen fertilization and inoculation on maize nutrition and productivity, depend on the cultivar used and the prevailing edaphoclimatic conditions. In this sense, the successful results found in the literature of the maize-Azospirillum association are related to factors of the bacterium itself, such as the choice of the strain, the ideal number of cells per seed and its viability, as well as the compatibility between strain and genotype used (Mehnaz \& Lazarovits, 2006).

As for the economic and financial factors of the study, total production cost per hectare, variations. The economic and financial factors regarding total production costs per hectare are presented in Table 3 . When inoculated, Feroz VIP3 and SCS-156 presented better economic and financial results, which were driven by the increase in silage productivity. Inoculated SCS-156 presented, overall, better results in terms of productivity and production costs. Profitability was calculated at $37.5 \%$ in year 1 and $38.7 \%$ in year 3, which makes it, among those evaluated crops, the most attractive for rural producers in terms of return on investments.

The calculated economic equilibrium, which refers to the minimum productivity required in order to pay all production costs, considering an average market value for all three years, hybrid Feroz VIP3 required 26.0 and 25.8 t.ha $^{-1}$ for inoculated and control respectively. Varieties SCS-154 and SCS-156, both required a yield of 24.6 and 24.4 t.ha ${ }^{-1}$, also for inoculated and control respectively. When comparing these values with the feed silage yield, for Feroz VIP3 without inoculation, this is zero, which indicates that the production obtained was just enough to cover production costs, since when inoculated; there is a positive balance of $3 \mathrm{t}^{-h^{-1}}$, resulting in a better rate of return on investment.

Under these same conditions, it is calculated that SCS-156 is a much more attractive cultivar for the grower, as there is a positive balance of 7.8 t.ha $^{-}$ ${ }^{1}$, and consequently, a higher rate of return, 30\% above the productive equilibrium point. On the other hand, when not inoculated, the silage yield for this variety was insufficient to cover production costs. For the SCS-154, regardless of the use of Azospirillum,

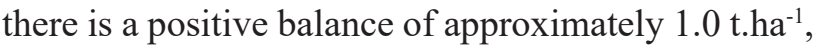
suggesting that inoculation serves no purpose for this variety. 


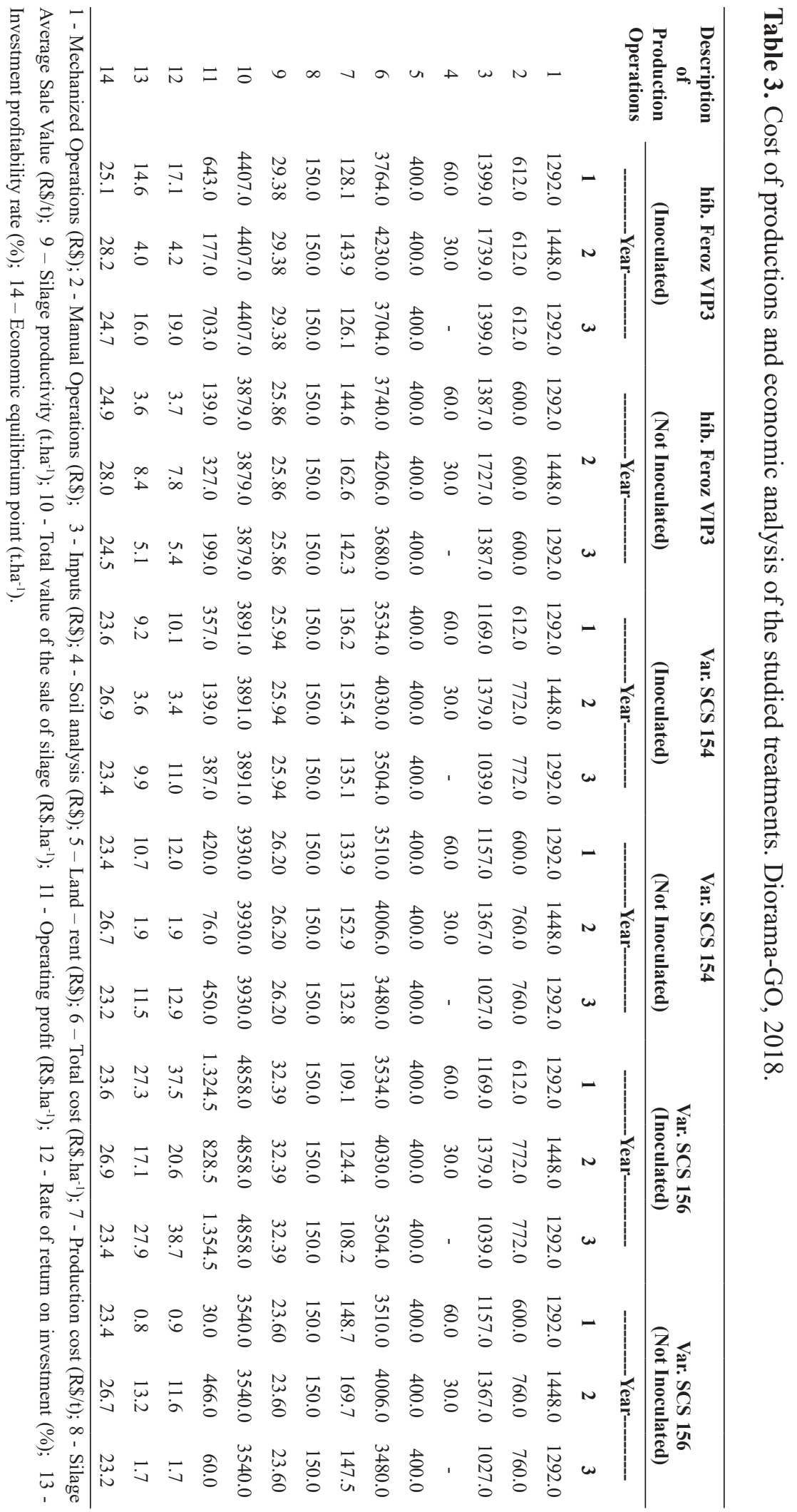




\section{Conclusions}

- The studied maize varieties had different responses to the inoculation of Azospirillum brasilense.

- The hybrid, Feroz VIP3 and Variety SCS 156, the use of Azospirillum provided better plant development, an increase in silage yield and a better protein composition of the produced forage feed.

- Inoculated Variety SCS 156 also proved to be economically more attractive and viable for rural producers, presenting an increased profitability.

\section{Acknowledgements}

The authors would like to thank the Instituto Federal Goiano, for their indispensable financial support in order to execute this study, EPAGRI for the genetic materials of maize and Microquimica for the inoculant.

\section{References}

ALVES, E. D. L.; BIUDES, M. S. Variabilidade temporal da precipitação em Iporá, GO - um estudo climatológico. Revista Ciências do Ambiente OnLine, v. 4, n. 2, p. 1-9, 2008.

CANTERI, M. G.; ALTHAUS, R. A.; VIRGENS FILHO, J. S.; GIGLIOTI, E. A.; GODOY, C. V. SASM - Agri: Sistema para análise e separação de médias em experimentos agrícolas pelos métodos Scoft-Knott, Tukey e Duncan. Revista Brasileira de Agrocomputação, v. 1, p. 18-24, 2001.

CRUZ, J. C.; PEREIRA FILHO, I. A.; SILVA, G. H. da. Produção de milho na agricultura familiar. Circular Técnica 159. 42p. 2011.
CUNHA, F. N.; SILVA, F. N.; BASTOS, F. J. C.; CARVALHO, J. J.; MOURA, L. M. F.; TEXEIRA, M. B.; ROCHA, A. C.; SOUCHIE, E. L. Efeito da Azospirillum brasilense na produtividade de milho no sudoeste goiano. Revista Brasileira de Milho e Sorgo, v. 13, n. 3, p. 261-272, 2014. DOI: http://dx.doi.org/10.18512/1980-6477/rbms. v13n3p261-272

DIAS, K. M.; SILVA, M. M.; WANDER, A. E.; SAlVIANO, P. A. P.; CARVAlHO, E. R. de A perspective for rural development based on the dairy-farming production system in Iporá and surroundings, Goiás State. Revista Verde de Agroecologia e Desenvolvimento Sustentável, v. 10, n. 3, p. 16-24, 2015.

DÍAZ-ZORITA, M. Avaliação da produção de milho (Zea mays L.) inoculado com Azospirillum brasilense na Argentina. In: Diversidade e inovações na cadeia produtiva de milho e sorgo na era dos transgênicos. Instituto Agronômico de Campinas. Associação Brasileira de Milho e Sorgo, 2012. p. 529-536.

DOBBELAERE, S.; CROONENBORGHS, A.; THYS, A.; PTACEK, D.; VANDERLEYDEN, J.; DUTTO, P.; LABANDERA-GONZALEZ, C.; CABALLE ROMELLADO, J.; AGUIRRE, J. F.; KAPULNIK, Y.; BRENER, S.; BURDMAN, S.; KADOURI, D.; SARIG, S.; OKON, Y. Responses of agronomically important crops to inoculation with Azospirillum. Australian Journal of Plant Physiology, v. 28, p. 871-879, 2001. DOI: https:// doi.org/10.1071/PP01074.

FERREIRA, J. M; MOREIRA, R.M.P.; HIDALGO, 
J.A.F. Capacidade combinatória e heterose em populações de milho crioulo. Ciência Rural, Santa Maria, v. 39, n. 2, p.332-339, 2009. DOI: http:// dx.doi.org/10.1590/S0103-84782008005000058.

HUNGRIA, M. Inoculação de Azospirillum brasiliense: inovação em rendimento a baixo custo. Embrapa Soja. 36p. Documentos- 325. 2011. 36p.

HUNGRIA, M.; CAMPO, R. J.; SOUZA, E. M.; PEDROSA, F. O. Inoculation with selected strains of Azospirillum brasilense and A. lipoferum improves yields of maize and wheat in Brazil. Plant and Soil, v. 331, n.1-2, p. 413-425, 2010. DOI: http://dx.doi. org/10.1007/s11104-009-0262-0.

MARINI, D.; GUIMARÃES, V. F.; DARTORA, J.; LANA, M.C.; PINTO JÚNIOR, A. S. Growth and yield of corn hybrids in response to association with Azospirillum brasilense and nitrogen fertilization.

Revista Ceres, v. 62, n. 1, p. 117-123, 2015.

MEHNAZ S.; LAZAROVITS G. Inoculation effects of Pseudomonas putida, Gluconacetobacter azotocaptans, and Azospirillum lipoferum on corn plants growth under greenhouse conditions. Microbial Ecology. V. 51, N.3, P.326-335, 2006. DOI: https://doi.org/10.1007/s00248-006-9039-7.

MORAES, G. P.; GOMES, V. F. F.; MENDES FILHO, P. F. ; ALMEIDA, A. M. M.; SILVA JÚNIOR, J. M. T. Adubação nitrogenada associada à inoculação com Azospirillum brasilense na cultura do milho. Revista Agropecuária Técnica, v. 38, n. 3, p. 109-116, 2017. DOI: https://doi.org/10.25066/agrotec.v38i3.29919.
SCHNEIDER, F. J. A.; MALLMANN, M. S.; BONFADA, E. B.; PORTELA, V. O.; BONFADA, E. B.; KAISER, D. R. Resposta da inoculação com $A$. brasilense nas culturas do trigo e do milho safrinha. Revista Scientia Agraria. v. 18 n. 2, p. 97-103, 2017. DOI: http://dx.doi.org/10.5380/rsa.v18i2.51475.

RODRIGUES, R.C. Métodos de análises bromatológicas de alimentos: métodos físicos, químicos e bromatológicos. Embrapa Clima Temperado, Pelotas-RS, Documentos 306, 2010. 177 p.

RODRIGUEZ, H.; GONZALEZ, T.; GOIRE, I.; BASHAN, Y. Gluconic acid production and phosphate solubilization by the plant growth-promoting bacterium Azospirillum spp. Naturwissenschaften, v. 91, p. 552-555, 2004. DOI: http://dx.doi.org/10.1007/ s00114-004-0566-0.

SCHAEFER, P .E.; MARTIN, T. N.; PIZZANI, R.; SCHAEFER, E. L. Inoculation with Azospirillum brasilense on corn yield and yield components in an integrated crop-livestock system. Acta Scientiarum, v. 41, e39481, 2019. DOI: http://dx.doi.org/10.4025/ actasciagron.v41i1.39481.

SKONIESKI, F. R.; FRATA, M. T.; VIÉGAS, J.; MARTIN, T. N.; NORNBERG, J. L.; MEINERZ, G. R.; TONIN, T. J.; BERNHARD, P. Effect of seed inoculation with Azospirillum brasilense and nitrogen fertilization rates on maize plant yield and silage quality. Revista Brasileira de Zootecnia, v. 46, n. 9, p. 722-730, 2017. DOI: http://dx.doi.org/10.1590/ s1806-92902017000900003.

MUMBACH, G. L.; KOTOWSKI, I. E.; SOUSA, D. M. G. de; LOBATO, E. (ed.). Cerrado: 
correção do solo e adubação. 2. ed. Brasília, DF: Embrapa Informação Tecnológica; Planaltina, DF: Embrapa Cerrados, 2004. 416 p.

SOUZA, E. M.; GALINDO, F. S.; TEIXEIRA FILHO, M. C. M.; SILVA, P. R. T.; SANTOS, A. C; FERNANDES, G. C. Does the nitrogen application associated with Azospirillum brasilense inoculation influence corn nutrition and yield? Revista Brasileira de Engenharia Agrícola e Ambiental. v. 23, n. 1, p. 53-59, 2019. DOI: http://dx.doi.org/10.1590/18071929/agriambi.v23n1p53-59.

SZILAGYI-ZECCHIN， V. J.; KLOSOWSKI, A. C.; IKEDA, A. C.; HUNGRIA, M.; GALLITERASAWA, L. V.; KAVACORDEIRO, V.; GLIENKE, C.; MÓGOR, A. F.; Potential inoculant strains of Brazilian endophytic bacteria for maize (Zea mays L.) growth promotion. International Journal of Agronomy and Agricultural Research, v. 7, n. 4, p. 128-134, 2015.
SZILAGYI-ZECCHIN, V., MARRIEL, I. E., DA SILVA, P. R. F. Produtividade de milho inoculado com Azospirillum brasilense em diferentes doses de nitrogênio cultivado em campo no Brasil. Revista de Ciências Agrárias. v. 40, n. 4, p. 795-798, 2017.

TEDESCO, M. J.; GIANELlO, C.; BISSANI, C. A.; BOHNEN, H.; VOLKWEISS, S. J. Análise do solo, plantas e outros materiais. 2. ed. Porto Alegre: Departamento de Solos - UFRGS. 1995.

THOMAZINI, G.; REICHEMBACK, M. P.; ARF, O.; GERLACH, G. A. X.; BUZETTI, S.; RODRIGUES, R. A. F. Inoculação de sementes com Azospirillum brasilense e doses de nitrogênio mineral em milho cultivado em sistema plantio direto. Revista Brasileira de Milho e Sorgo. v. 18, n. 3, p. 396-407, 2019. DOI: https://doi.org/10.18512/1980-6477/ rbms.v18n3p396-407.

TEIXEIRA, P. C.; DONAGEMMA, G. K.; FONTANA, A.; TEIXEIRA, W. G. (ed.). Manual de métodos de análise de solo. 3. ed. rev. e ampl. Brasília, DF: Embrapa, 2017. 574 p. 